\title{
Protecting the Subjects of Credit Reports
}

One prominent feature of the affuent society is consumer credit. ${ }^{1}$ Credit suppliers try to minimize risk by buying information on prospective borrowers from specialized reporting bureaus.2 Accuracy is important to those seeking information; it is critical to those reported on. But mistakes are common. Their detrimental impact on the subjects of credit reports may be great, and the prospect of centralized records only portends a wider distribution of harmful information. Discovery of mistakes by the subject is made difficult by industry secrecy. Thus, relief is seldom sought. Further, rare attempts to gain judicial relief have been stymied by an inappropriate application of the defamation doctrine.

To deal with some of these problems, Congress has recently passed the Fair Credit Reporting Act (FCRA). ${ }^{3}$ It is a first, if short, step toward solution, but may cause more problems than it solves. This Note will identify the injuries and costs of credit reporting and suggest that enterprise liability and further legislation are required for the protection of the consumer.

1. Consumer credit includes short term, non-installment debt, including charge accounts, debts for professional services, and credit ards, and longer term installment debts, such as conditional sales contracts for consumer durables, home repair and modernization loans and personal loans.

Total consumer credit outstanding exceeds $\$ 112$ billion. U.S. Bußsau of miz CENisus, STATISTICAI ABSTRACT OF THE UNITED STATES 460 (1969). It is extended at the rate of $\$$ billion per month. Trare, Dec. 20, 1968, at 79. Its growth in size and importance is one of the main economic developments of this century. In 1930, consumer credit totalled $\$ 5.8$ billion and was less than $8 \%$ of disposable personal income. In 1949 it had risen to $\$ 17$ billion and $8.9 \%$. U.S. BUREAU OF THE CENSUS, HLSTORICAL STATISTICS OF TIIE UNTED States, Colonial Times to 1957, Tables X 415-422, F 6.9 (1960). Consumer credit was equal to $19 \%$ of disposable personal income in 1969 U.S. BurEau of the Census, StatisTICAL ABSTRACT OF THE UNTrED STATES 317 (1969).

2. These are to be distinguished from credit collection bureaus, which attempt to collect delinquent debts for creditors, although on occasion the credit bureau will both report and collect. Credit reporting bureaus are sometimes distinguished from "retail credit bureaus" whose function is to supply credit information to a group of retail merchants in a community. The difference is far from clear, and for purposes of this Note it is assumed that all arguments pertinent to what I call credit reporting bureaus also pertain to "retail credit bureaus."

3. Fair Credit Reporting Act $\$ \$ 601-622,15$ U.S.C.A. $\$ \S 1681-1681 t$ (Supp. 1971). For a discussion of the provisions and shortcomings of the Act, see pp. 1061-67 infre.

4. For an excellent treatment of the whole problem of information gathering, with an emphasis on problems of privacy, see Miller, Personal Privacy in the Compuler Age, 67 Mrar. L. REv. 1091 (1969). See also Note, Credit Investigations and the Right to Prvacy: Quest for a Remedy, 57 Geo. L.J. 509 (1969); Rarst, The Files: Legal Controls Over the Accurccy and Accessibility of Stored Personal Data, 31 LAw \& Contestr. Pros. 342 (1965); Caplovitz, Consumer Credit in an Affluent Society, 33 LAw \& Contrur. Pros. 641 (1963); W REELER, ON RECORD: FILES AND DOSSIERS IN ASTERICAN IIIFE (1969). 


\section{The Market for Credit Information}

\section{A. Nature of Credit Reporting}

Considerations of time and expense underlie the credit grantors' reliance on reporting bureaus for information. ${ }^{5}$ Bureaus sell capsule histories-descriptions of an individual's financial, personal and public life. ${ }^{6}$ Almost every important transaction a person attempts to engage in, other than a cash purchase, will involve a credit check, and the transaction wll depend on the report.

Credit reporting bureaus have two primary sources of information, their investigators and their customers. The typical credit investigation is not conducted in a manner that compels confidence in the report. Taking an average of 30 minutes, ${ }^{7}$ an initial investigaton is carried out by an inspector who is usually paid on a piecework basis. He may receive $\$ 1.80$, about half of the bureau fee, and must prepare each report. ${ }^{8}$ In addition to depending on their own investigators most credit reporting bureaus receive and record the credit records of their customer's debtors. ${ }^{9}$

5. The Bank of America, for instance, turned over eight million pieces of information on individual credit to Credit Data Corporation, a California-based credit reporting bureau which maintains files on over twenty million persons and is adding new files at the rate of fifty thousand per week. Hearings, infra at 83.84. Credit Data estimates that it would take five years to have a file on every American on their computer tapes.

A trade group of 2200 local credit bureaus, the Associated Credit Bureaus of Amcrica (A.C.B. of $A$ ) have ninety million on file and issued 97.1 million credit rcports in 1967 to over 400,000 customers in 36,000 places in this country and abroad. Hearings on Commer. cial Credit Bureaus Before a Subcomm. on Invasion of Privacy of the House Comm. on Government Operations, 90th Cong. 2d Sess., at 5, 64 (1968). [Hereinafter cited as Hear. ings.]

6. Credit decisions are based on "the three C's"-capital, capacity, and character. Brack, BUY Now Pay LATER 46 (1961). These include the subject's net worth, earning capacity in the future, and debt paying record, although the penumbra of "character" extends much further. Credit reports mix personal, sensitive, and public record matter. The typical credit file includes personal identity, employment history, public records such as arrests, law suits, filed judgments, marriage, divorces and bankruptcics. Credit history, size of charge and bank accounts, "slow pay" or "no pay" records, defaults, and other data are included. For special credit investigations, such as those for insurance com. panies, information on personal character, habits and reputation is obtained primarily from conversations with one's neighbors, employer, landlord and fellow workers. 115 CONG. REC. 2410 (1969).

Some large credit bureaus do not include capital or capacity and rely mainly on char. acter. Credit Data's files contain the information that a person is a homeowner only if there is an outstanding mortgage loan on it. They rccord that he is employed, but do not record salary since employment is considered only a secondary means of identification. Hearings, supra note 5 , at 67,88 .

7. I15 Cong. REc. 2410, 2413 (Jan. 31, 1969). This investigation is required to set up a file and is done at the request of a credit grantor which requires a report on someone for whom the bureau has no record. This is common for insurance companies. Many creditors merely reject the applicant if the credit bureaus they patronize have no rccord at all on the person.

8. V. PACKARD, THE NAKED SOCIETY 176 (1964). This is the initial report. Later reports on the same subject are considerably cheaperi varying between $40-63 \xi$. Hearings, stcpra note 5 , at 157 .

9. The Bank of America relies exclusively on credit reports and turns all its credit records over to Credit Data Corporation. See note 5 , stepra. 
The bureau does not check further or analyze the information from either source..$^{10}$ Data is simply collected, organized and transmitted. Information users normally telephone the bureau, listen to the report, and make an immediate decision without verifying the information. They assume that the credit bureau has done that already.

Most people are unaware of either the existence of their credit file, and its location or its contents, and, thus, do not inspect it. Moreover, contracts between credit bureaus and subscribers may have a non-disclosure clause in which the subscriber pledges not to show the report to the subject. The bureau desires subscriber secrecy to protect itself from lawsuits based on erroneous reports.

It is unlikely that the subject will know that his application for credit has been rejected when the cause is an unfavorable report. Credit grantors file away applications they reject to avoid offending the applicant by a straightforward statement of unacceptability. He will simply never hear from the store, insurance company, loan company, bank or employer again, and not know why.11

A credit bureau may consult with a subject to advise him how to improve his credit rating, but it normally will not show him the report or mention specfic details. ${ }^{12}$ This secrecy and reluctance to disclose information to the subject of the report deprives the credit reporting system of a much needed method of accuracy control. As long as there is no feedback, bureaus will be unaware of correctible mistakes and will have little incentive to find them. ${ }^{13}$

\section{B. Injuries the Subject May Suffer}

Reports that create a false impression of the subject's actual conduct in the minds of decision makers constitute an obvious injury to the

10. See Hearings, supra note 5 , at 88 .

11. 115 CoNG. REc. 2410, 2412 (Jan. 31, 1969).

12. A familiar tactic is to place a nuisance charge on the consultation or to place the date of the interview weeks away. 115 CoNc. REc. 2410, 2412 (Jan. 31, 1969). During hearings on the regulation of credit reporting bureaus the following exchange took place:

Mr. (Congressman) Rosenthal: Could jou call up and get a copy of iny record, if I

have one with your company and let me look at it?

Mr. Jordan (Credit Data Corporation): No.

Mr. Rosenthal: "No" to which part of the question? No, you couldn't all up, or No,

you don't know if you have it, or No, you couldn't let me see it?

Mr. Jordan: I guess all three.

Hearings, supra note 5, at 72 .

13. One of the most powerful incentives to safety by producers and sellers is the avoidance of a reputation for selling unsafe products. When the harm is concealed, this incentive is absent. Plant, Strict Liability of Manufacturers for Injuries Caused by Defects in Products-An Opposing Tiew, 24 TENN. L. REv. 938, 945 (1957). 
applicant for credit, employment, mortgage, insurance, lease, or loan. The injury may assume several different forms.

First, misleading or incomplete information may be reportecl. A bureau may record and report one subscriber's statement that the subject does not pay his bills or pays them very late. It does not record the reason, which may be a dispute over defective merchandise, unemployment, or illness. ${ }^{14}$ Similarly, credit bureaus cull newspapers and court records for arrests, liens, lawsuits filed, divorces, indictments, and convictions, but do not, in most cases, determine final dispositions of law suits. ${ }^{15}$

Second, wholly incorrect information may be reported, as in cases of mistaken identity. ${ }^{16}$ In one recent case a credit bureau reported the plaintiff to have gone bankrupt, to have been subject to various inquiries into unethical business behavior, and to have been the sub. ject of an "undesirable loan" report from his bank. All statements were false, and the source of the mistakes could not be traced. ${ }^{17}$

Third, defamatory information may be reported. This category neces. sarily overlaps the last since falsity is an element of defamation, but not all falsehoods are defamatory. ${ }^{18}$ Many credit reports contain unverified hearsay, such as a neighbor's views on the subject's marital relationship, sexual proclivities, drinking or drug-taking habits, and

\section{Hearings, supra note 5 , at 76.}

Mr. (Representative) Rosenthal: Let's suppose a television set that I bought on credit doesn't work well and I tell them I am not going to pay until the set is fixed or replaced, and I don't pay for 2 or 3 months and we have this dispute going, what hap. pens to my credit rating?

Mr. Jordan (Credit Data Corporation): If you refuse to pay for the television set, the subscriber's accounting system, unless he inhibits it, will record the fact that you are 60 days delinquent. This is a fact of your credit experience.

Mr. Rosenthal: So because of the fact that he sold me a bum television set $I$ can't go out and get a mortgage and buy a new house?

Mr. Jordan: Whether you can get a mortgage depends on the mortgage lender's in. terpretation.

Mr. Rosenthal: The mortgage lender from reading your record wouldn't know that I am a pretty good guy, but there is a dispute over a television set; he would get a piece of cold information that would have me marked as a delinquent.

Mr. Jordan: He would have the facts which are undeniable that you did not pay your bill.

15. They do not devote any manpower to the task of obtaining and recording informa. tion of dismissed charges, police records expunged due to unjustified arrest, lawsuits settled out of court or dismissed, indictments quashed or convictions reversed on appeal. Id. at 10.

16. A New York State assemblyman was recently refused a major credit card due to an "unfavorable" credit report, based, he discovered after repeated phone calls, visits and threats of legislative action, on an outstanding judgment against someone of a similar name. Sesser, How Credit Bureaus Collect and Use Data on Millions of Persons, Wall St. Journal, Feb. 5, 1968, at 1. What happens to the person without political leverage?

17. Petition of Retailers Commercial Agency, Inc., 342 Mass. 515, 174 N.E.2d 376 (1961).

18. W. PrOSSER, THE LAW OF TORTS 825 (8rd ed. 1964). 
general reputation. ${ }^{19}$ Almost any statement of this kind will be defamatory if untrue, and many false statements which are significant enough to lead to denial of credit will be defamatory.:0

Fourth, a person may be coerced into abandoning his legal rights by a merchant's threat to harm his credit rating. If a person knows nothing else about his credit identity, he is aware that a "good credit rating" is very important. Unscrupulous businessmen are aware of this too. When a buyer withholds payments on defective merchandise which the seller refuses to repair or replace, the buyer is exerting his only leverage. Settlement on the merits is made impossible by the knowledge, shared by buyer and seller, that there is a third party to the transaction, the credit reporting bureau, which will receive and pass on the seller's version. The seller will neither settle nor sue. He will remind the buyer that his credit rating will self-destruct if he persists in asserting his position. ${ }^{21}$ Retailers and others can thus exert powers exceeding those their economic positions alone could confer. The credit reporting system encourages and increases overreaching.

Fifth, the harm done by defective reports is exacerbated by the dissemination of personal information to a wider audience than the subject has anticipated or consented to. An applicant for credit or other financial transaction usually signs an application in which he authorizes the company to investigate his credit record.22 But the permission is strictly pro forma, and user access to the report is unconnected with the presence or absence of subject consent. Despite industry disclaimers ${ }^{23}$ evidence exists that credit files can be obtained by nearly anyone with great ease, ${ }^{24}$ including police agencies, the Federal Bureau

19. Sesser, Big Brother Reeps Tabs on Insurance Buyers, THE New REPunuc, Apr. 27, 1968, at 11. Frederick E. King, president of Hooper-Holmes, the largest insurance applicant investigator, describes the procedure. "You go to a neighbor and establish rapport, ... Then you ask, 'What's your opinion of X's home life; how do you think of him as a family man?' This will usually elicit some hint. . . Then you start digging. You press them as far as they go, and if they become recalcitrant, you go somewhere else." Id.

20. See pp. 1049-50 infra.

21. See note 14, supra.

22. Hearings, supra note 5 , at 28 . A common consent form is the following:

$\mathrm{I}$ hereby authorize the person to whom this application is made, or any credit bureau, or any other investigative agency employed by such person, to investigate the references herein listed, or statements, or other information, oral or mritten obtained from me, or any other person pertaining to my credit and financial responsibility. . . . I hereby release any claims, damages and suits whatsoever which may at any time be asserted by me by reason of such investigation.

23. Industry spokesmen claim that only "subseriber companies, all of whom are bona fide credit grantors who have agreed to conditions restricting their access to and use of the information" may receive reports. "No one else is permitted access for any reason whatcoever." Hearings, supra note 5 , at 64 .

24. The striking disparity between industry doctrine and practical reality ras demonstrated last year by CBS News. According to John Spafford, Executive Director of the 
of Investigation, ${ }^{25}$ and the Internal Revenue Service, since information is routinely available to anyone willing to pay the going rate..$^{23}$

Many inquiries do not involve credit and thus raise important issues of privacy and propriety in access to "confidential" matter by government agencies and others who need not show cause to judicial authorities. ${ }^{27}$ The potential damage from a mistaken report is drastically increased in these cases, in which a person has no reason to know or be. lieve he is being investigated, has not given even cursory consent, and may never know of the damage, let alone its cause. ${ }^{28}$

Further, the collection and centralization in computers of large quantities of information with instant and easy access from anywhere in the country introduces a new parameter to the problem. As centers of computerized data are linked together on a national and international basis, the potential damage and scope of dissemination of an erroneous report are increased geometrically. ${ }^{29}$

\section{Demand for Credit Reports}

The demand side of the credit information market cannot be described with precision. Nevertheless, several generalizations are possible.

Associated Credit Bureaus of America, to get a credit report from any of the affiliated bureaus: (1) the firm must be a bona fide grantor of credit to individual consumcrs, and (2) must apply to a local member credit bureau, (3) which will investigate the firm asking for the report to make sure that it meet the qualifications of (1) above, and (4) will re. quire the firm to sign a contract with the bureau agreeing to conform to its practices. CBS invented a bogus firm, a "systems company," and registered it with a company that provides a mailing address, phone service and printed letterheads to business which do not wish to rent office space, all for $\$ 25$. They mailed twenty letters to creclit bureaus in various cities asking for reports on individuals picked at random from those cities phone books, claiming that they were considering granting credit to the person inquired about. They received without further question ten full reports. Two bureaus offered to send informaion if a contract were signed. Four didn't reply and only two referred them to the local bureaus as required by the association rules. Deciding to make it more difficult, CBS tried one more mailing in which they no longer stated that they were thinking of granting credit. They wrote for reports on persons who had complained to congressmen of their troubles with credit bureaus, and between the two mailings, a tougher set of code regulations had gone into effect. Of twenty-eight letters sent, thcy received seven reports, twelve referrals to local bureaus, one flat refusal, three offers of contracts, and five did not respond. They signed one of the contracts and received a full report within a few days.

25. F.E. King, President of Hooper-Holmes Bureau, which maintains files on over 51 million insurance applicants, states, "The FBI can do just about anything they want to. They're constantly in our files." Sesser, supra note 19.

26. Black, supra note 6 , at 36 .

27. See generally, Note, Credit Investigations and the Right to Privacy: Quest for a Remedy, 57 GEO. L.J. 509 (1969).

28. The problem is not limited to governmental agencies pursuing their own objectives. Private detective agencies, marketing research firms, litigants scrcening jurors for voir dire, country clubs, even fiancees, consult credit bureaus.

29. Miller, Personal Privacy in the Computer Age: The Challenge of a New Technology in an Information Oriented Society, 67 Mich. L. REv. 1091 (1969). 
Information is indispensable for credit decisions. In an impersonal and highly mobile society, risk reduction requires the fullest possible knowledge of the prospective debtor's solvency. Virtually every creditor obtains information from the applicant and checks it. In the normal transaction, the creditor checks with a creditor reporting bureau. ${ }^{30}$

There is no satisfactory, economical substitute for a credit bureau report. The creditor can: (1) do nothing, relying on the application; (2) undertake an investigation on its own; (3) hire a private investigator; or (4) buy a credit report. The first alternative involves an unacceptable level of risk. ${ }^{31}$ The second would result in high administrative expenses which even the largest corporations are normally unwilling to undertake. ${ }^{32}$ Private detective services are extremely expensive relative to credit reports.

Thus, most creditors rely exclusively on credit reports for pre-decision information. Since independent investigations of applicants are expensive and the risk of acting without outside information is high, most creditors will reject the applicant on whom the credit bureaus with which they deal have no report. ${ }^{33}$

The danger has been limited in the past for several reasons. (1) Large quantitio of information about individuals have not been collected and therefore have not been available; (2) the available information generally has been maintained on a decentralized basis; (3) the available information has been relatively superficial in character and often has been allowed to atrophy to the point of uselessness; (4) the available information wias difficult to keep track of, and (5) most people are unable to interpret and infer revealing information from the available data. Id. at 1108. The translation of raw dati from alphabetic notation to the appropriate computer format introduces one new processing stage susceptible to human error. Clerical error in data processing can be extremely damaging. With data retrieval cheap and storage expensive, computer programming is likcly to be rigid and highly categorized, with spectral categories of conclusory terms, (good, fair, poor, etc) which would have even less breadth than the incomplete report of the paper file. Information stored far from the point of original recording and emplojed for purposes different from those for which it was collected vill cause difficult evaluative problems. Another diffculty is the human response to computer data. It is considered to have a higher degree of probity than data reported by a person. The facts which emerge from the computer tend to become the only significant facts on the subject. Evaluative decisions on the basis of raw data will probably be turned over to computers on a formula basis, further reducing the flexibility of decision-making and the likelihood that explanatory matter will accompany soft data. The expensive operation of computers dictates time sharing: thus data may become accessible to others than the bureau since security techniques by the computer industry are minimal. The centralization of formerly decentralized stores of information irill mean that one invasion will secure for the intruder vast quantities of data that formerly could be obtained only by many penetrations. Thus, there are unacoounted-for costs in the cost-saving economics of computerization.

30. See, e.g., p. 1053 infra.

31. The occasional exception for whom this level of risk is acceptable is the ghetto merchant who may prefer coercive collection practices to detailed pre-credit screening. An increased price of credit reports could lead to a shift toward more cocroive collcction. Thus, the demand for credit reports is relatively, not completely, inelastic. See Leff, Injury, Ignorance and Spite-The Dynamic of Coercive Collection 80 YALE L.J. I (1970). 32. The Bank of America is a good example. It discontinued investigations and hired Credit Data Corporation to do the job. Hearings, supra note 5, at 83-84.

33. Conversations with officers of the Security National Bank, Oakland, California, 
Given the need for credit information, the lack of adequate substitutes for the credit report, and the heavy reliance upon credit reporting bureaus, the following assumption, used throughout this Note, is made: The demand for credit reports is relatively inelastic, and thus the number of credit reports purchased will be somewhat insensitive to price changes. Although a rise in the price would lead to some reduction in the number of credit reports purchased, total dollar sales would rise. ${ }^{34}$

\section{Putting the Burden on the Bureaus}

The cost to society of credit reporting accidents is high. In evaluating the effectiveness of laws which apply to credit reporting bureaus, the basic issue is which liability rules will minimize the total cost to society of credit reporting accidents. Two questions are critical: (1) Which party is the cheapest cost avoider, i.e. should bear the cost of accidents? (2) What mix of judicial and legislative rules achieves the lowest cost?

In The Cost of Accidents, ${ }^{35}$ Professor Calabresi provides a framework for answering these questions. He divides the cost of accidents into several categories. "Primary" accident costs measure the direct loss to accident "participants," such as loss of earnings, damage to property, and out-of-pocket expenses, ${ }^{30}$ and the costs of avoiding accidents. Primary costs should be borne by the "cheapest cost avoider," the party which can best assign the costs to the harm-causing activity, predict them most accurately, and insure against them at the lowest cost. "Secondary" costs are the avoidable social costs of accidents-loss of economic position and social status, alienation and emotional suffering-caused when large losses fall on the individual victims. ${ }^{38}$ The level of secondary costs is inversely related to the degree of cost spreading, among people and over time.39 "Tertiary" costs are the costs of administering legal rules, either through judicial machinery or an administrative counterpart. ${ }^{40}$ Because the types of cost are interrelated,

August 15, 1969, and Manager, Smolen's Furniture, New Haven, Connecticut, September 20,1970 .

34. For an excellent introductory discussion of the concept of elasticity of demand, see P. SAMUELSON, ECONOMICS, 363-67 (7th ed. 1967).

35. G. Galabresi, The Costs of accidents, a legal and Economic Analysis (1970).

36. Id. at $26-27$.

37. Id. at 143-73.

38. Id. at $27-28$.

39. Id. at 39-40.

40. Id. at 28-29. 
one object of liability rules is to minimize the net sum of primary, secondary and tertiary costs. 11

Primary cost reduction may be attempted through one or a combination of two approaches. The "general deterrence" or "market" method, ${ }^{42}$ working through judicial rules, places on economic activities the cost of the accidents they cause. The impact of this deterrent is felt in market transactions, and financial incentives to reduce the risk of the activity are thereby created. Businesses will institute safeguards to make their activities safer, up to the point where it becomes cheaper to buy liability insurance. 33 "Specific deterrence," or the "collective" method, ${ }^{44}$ proscribes or restricts the harm-causing activity directly by legislation rather than working through the market. When a harmcausing activity is also socially useful, as is credit reporting, limitation rather than prohibition is appropriate. ${ }^{45}$ At this point, the question is which party, the bureau or the subject, is the cheapest cost avoider, and as such, should bear the primary costs.

According to a prominent economic theory, ${ }^{\text {to }}$ the choice of primary cost bearer will have no effect on the "real" price of the product. If this theory were correct in practice there could be no general deterrence, or primary cost reduction, in shifting cost from the victim to the producer. This theory reasons that if a seller of a product is liable for the injuries he causes, the cost of his safeguards and insurance raises the price of the product. If the user or consumer bears the cost, he will insure against accidents, and the cost of the product will be that much lower. The total price of the product plus insurance would in theory be the same either way.

In reality, however, there are several reasons why it makes a difference who bears the primary cost, reasons which suggest the bureaus should be primary cost bearers. Saying it makes no difference

presupposes an all knowing, all rational economic world which does not exist. In the first place, even if such a world did exist, some risks would still be assignable to the activity which caused them by only one party. ${ }^{47}$

Thus, the credit report's subject, even if he considered buying defama-

41. See p. 1054 infra.

42. G. CALABREST, supra note 35 , at 68.94 .

43. Id.

44. Id. at 95-129.

45. Id. at 68-69.

46. Id. at 162 .

47. Calabresi, Some Thoughts on Risk Distribution and the Low of Torts, 70 YAIP

L.J. 449, 506 (1961). 
tion insurance because of the risk of being defamed, would not be able to make this cost part of the price of credit reports because he doesn't buy the reports. Report buyers, who wouldn't need or buy the insurance since they are not the ones endangered, would buy just as many reports, even though their purchases raised the cost of defama* tion insurance to the subjects. Thus, as between bureau and subject, the bureau is the only party which can assign the cost of accidents to the price of the reports. Therefore, to reduce primary cost, the cost of accidents should be imposed on the bureaus.

Next,

one of the two parties may, in practice, be far more able than the other to evaluate the accident risk, i.e. the expected accident costs. And if this is the case, his activity is better suited (in terms of deterrence of accident prone activities) to bear the initial loss. ${ }^{48}$

It is a fair assumption that credit reporting bureaus know more accurately the expected cost of using the reports than do the subjects of the reports. Since the bureaus are better able to evaluate the risks, they are better able to find the best mix of safeguards and insurance. Imposing the primary cost on them will force them to do so. ${ }^{40}$

A third reason why it matters who bears the primary cost is that

it may not cost the two parties the same amount to insure against the loss. If the loss is placed on the party for whom insurance is less available or more expensive, a false cost-the excess cost of his insuring-will in effect be made a part of the price of the goods..$^{50}$ Liability insurance is common, and routinely available in the commercial world. ${ }^{51}$ It would probably be cheaper and easier for bureaus to insure than it would be for all potential credit report subjects to do so. 52

The credit reporting bureau is thus able to assign the cost which the subject cannot, to evaluate the costs more accurately than the subject can, and to insure against them at lower cost. The bureau would

48. G. Calabrest, supra note 35 , at 168.

49. There would be a few situations in which the subject would be better able to evaluate the risk and therefore be the cheapest cost avoider. This would be the super'sensitive person for whom a mistaken report would be a critical trauma, and the person for whom the particular transaction is his only opportunity of that kind. 'Thliese are rare situations, however, and a choice of cheapest cost avoider depends on a general validity which may not be correct in some individual situations, but which ustully will be.

50. G. CALABRESI, supra note 35 , at 164.

51. See DENENBERG, RISK AND INSURANCE (1964) 364-75.

52. If insurance against the risk of defamation were available, the transaction costs involved in requiring every potential subject to insure would be astronomicill. Truts. action costs would be much lower if bureaus do the insuring. 
be the cheapest avoider of primary costs, and imposing the cost on it would achieve the best general deterrence.

Imposing liability on credit bureaus would also reduce the secondary costs of reporting accidents. It has been contended that losses are least disruptive to society, socially and economically, when they are spread widely among people and over time. ${ }^{53}$ Thus, taking one dollar from each of 10,000 people-interpersonal loss spreading-causes less dislocation than taking $\$ 10,000$ from one person. Similarly, the benefit of intertemporal loss spreading is that spreading losses over time is less harmful than imposing the whole burden when the loss occurs. Though the widest loss spreading would be achieved through social insurance, enterprise liability is preferable because it works through the market and reduces primary cost. ${ }^{54}$

Holding credit reporting bureaus liable for their accidents would achieve wide loss spreading. The cost of safeguards and insurance would become part of the price of reports. Assuming relatively inelastic demand for credit reports, ${ }^{55}$ the cost would be passed on to report buyers. They would make the increased cost part of the price of credit, and each consumer of credit would pay a small part of the cost..$^{\circ 6}$ Loss would thus be spread from individual victims to all potential victims.

Insofar as the cost of mistakes cannot be passed on by the bureaus, they should absorb them because they are financially better able to do so than are the victims. ${ }^{57}$ This is the "deep pocket"ss aproach to risk spreading, based on the view that when the party with the deep pocket must absorb part of the cost, society's secondary costs are lower than they would be if the party with the shallower one absorbed it. As a general rule, the commercial enterprise has a deeper pocket than the person its activities harm. ${ }^{69}$

53. Id. at $39-45$.

54. Id. at 54 .

55. See p. 1042, supra, pp. 1053-54 infra.

56. The degree to which credit grantors can pass on incrensed costs of operation depends on the elasticity of demand for their products. The allocation of costs, howerer, is also an accounting concept. Increased cost of credit reports, as a matter of internal cost accounting, is likely to be allocated to the credit operation. Since the charge for consumer credit often is more related to the maximum charge allowicd Iegally than to the cost of a credit operation, the extent to which increased costs will be absorbed or passed on is un. clear. Credit offered by retail stores and finance companies normally costs the legal maximum. This is not true for commercial banks.

57. Although this is probably untrue on occasion, it is the assumption which underlies other areas of the law-products liability for example. As a general matter the enterprise is assumed to have a deeper pocket than the individual customer or user. The deep pocket approach is more applicable in theory than in practice as it applies to credit reporting bureaus, however, if the demand for reports is inclastic See pp. 1053.54 infro.

58. G. CaLABRESI, supra note 35 , at 40 .

59. One further aspect of secondary cost is the dislocation which would result if the 
If liability were placed on credit reporting bureaus, tertiary, or administrative, cost would rise due to a trade-off with primary and secondary costs. In a system where injured parties have no cause of action, there are virtually no administrative costs, although primary and secondary costs will be very high. A good scheme for reducing the latter, such as enterprise liability, will be more expensive administratively than other schemes, but it reduces primary and secondary costs very effectively. Further, any liability structure which depends on a case-by-case determination with judge and jury is expensive to administer. ${ }^{60}$ Enterprise liability is cheaper than a fault system because reasonable care issues are removed from the case. Ultimately, as Calabresi points out, ${ }^{61}$ once one chooses a cost avoidance system, administrative costs become primary costs and cannot be analyzed separately. The choice of a system must be based on a rough guess of who is the cheapest cost avoider and what system best reduces total accident costs.

As noted, in this case it appears to be the enterprise, the credit reporting bureau. As the locus of the two critical processes, information collection and dissemination, and money collection and expenditure, the bureau is ideally suited to evaluate and reduce the risk of injury, as well as spread the cost of injuries. In sum, if efficient primary, secondary and tertiary cost reduction were the sole criterion in structuring regulations, liability for credit reporting injuries arguably ought to be placed on the bureau.

It may be that this rough guess is incorrect, because costing out judicial changes is difficult and imprecise. Thus, it may be that a system which seeks to prevent, reduce, and compensate for injury to innocent persons costs society more than one which doesn't bother. But cost is not the only criterion-liability rules must also be fair.

In torts, fairness involves compensating relatively innocent victims by making relatively wrong-doing harm-causers ${ }^{22}$ pay or allocate the costs. ${ }^{63}$ Fairness also requires a reasonable and convenient process for adjudicating claims. In credit reporting, however, innocent persons

increase in cost to the bureau or its customers causes firms to go out of busincss. While this is a potential problem, inelasticity of demand suggests it is a rather small onc. Further, a basic premise of a free enterprise market economy is that inefficient businesses should go out of business. Only when this happens will the forces of supply and demand achicre the most efficient overall allocation of resources.

60. G. CAIABRESI, supra note 35, at 251.

61. Conversation with Professor Calabresi, March 16, 1971.

62. There may be a contradiction in saying that an act which is not preventable by exercising due care is an act of "wrong.doing." The term simply means that as between the parties, though both be "innocent," the party who causes the injury in fact is a "wrong-doer" relative to the victim who played no part in causing the injury.

63. G. CALABRESI, supta note 35, at 302-05. 
who are falsely characterized, defamed, improperly exposed, or coerced ${ }^{\text {ct }}$ have no recourse against credit bureaus whose sole motive in knowingly exposing persons to risk of harm is profit. Enterprise liability would correct this inequity. Further, it is unfair if tortfeasors can, by secrecy or concealment, avoid responsibility for the harm they do. Yet, due to insufficient regulation, credit bureaus are able to do so.

\section{Arguments for the Status Quo}

Arguments for making the liability rules more fair gain even more force when the gross inadequacy of the bureaus' justifications for present practices is considered.

Discussions of the harm done to individuals by credit reporting bureaus generally conclude that the harm done is very little in comparison with the benefit received, and that relatively few persons are injured by false reports. ${ }^{65}$ Such statements are not based on empirical evidence and are self-serving. No one can ascertain how many persons are harmed by faulty or improperly released reports because secrecy by grantors and bureaus prevents subjects from learning when a credit report has harmed them or whether the report is erroneous.

But given the lack of evidence to support the bureaus' claims and the demonstrated difficulty of discovering mistakes, this Note proceeds on the assumption that the people who have discovered the source of their injury are the tip of the iceberg, with a much larger portion below. ${ }^{68}$

One justification advanced by credit reporting bureaus for their secrecy is the claim that allowing the consumer to see his file would dry up sources of information. For example, stores may not be willing to turn their credit records over to the bureau if their customers will find out that the store reported them as "slow pay." The store still wants their business and doesn't want to offend.

This argument is specious. Creditors rely on the exchange of information among themselves, via the credit report, to reduce the risk in credit decisions. Their continued need for credit information and the gain obtained therefrom will, if the assumption that demand for reports is inelastic is correct, ${ }^{67}$ outweigh the loss of patronage from of-

64. See pp. 1038-1040 supra.

65. See, e.g., Smith, Conditional Privilege for Mercantile Agencies, 14 Coluss. L. REv. 187, 207, 296 (1914).

66. See p. 1037 supra.

67. See pp. 1041-42 supra, pp. 1053-54 infra. 
fended customers. Assuming, further, that all stores of a particular type use credit reports, consumers seeking credit could not choose one store over another because one reports the transaction and the other does not.

Moreover, as noted, this secrecy allows credit bureaus to avoid responsibility for the harm they do by hiding the harm, and prevents correction before more harm is done. Even if it were true that opening the system caused some reduction in the quantity of information compiled, credit grantors should not be allowed to work both sides of the street. If credit grantors wish and need to exchange information on their customers they should do it openly, alerting their customers to the danger of late payment, and offering them the opportunity to participate in the credit granting process.

A second justification for current practices is that the self-interest of credit bureaus will assure the accuracy of credit reports. If the reports aren't accurate, those who buy them will get their information elsewhere.

Although bureaus and their customers do have an economic interest in the validity of information this does not assure care and accuracy. In a system with no feedback, sales are lost due to false negative reports. But these losses are hidden from the potential buyer who, thus, cannot bring errors to the seller's attention. Credit grantors have no incentive to go elsewhere when they are unaware of reports that err against the consumer. Since the object of credit reports is to weed out bad risks, false positive reports, ${ }^{68}$ in which the bureau has failed to dis. cover the detrimental truth, are probably less frequent than negative mistakes. When positive mistakes lead to losses they may be attributed to random error or misevaluation of data. Even if error were suspected, a demand for greater accuracy would mean more intensive pursuit of negative information, not greater efforts toward balance, objectivity, accuracy and overall fairness. Such a shift toward "greater objectivity" would just increase the number of negative mistakes.

Nevertheless, mistakes are harmful to the credit grantor, the applicant and other borrowers. ${ }^{89}$ They currently go undiscovered. An open

68. The mistakes considered here are those in which credit bureaus fail to alert the credit grantor to risk factors upon which the grantor would have decided not to grant credit if those factors had been brought to its attention. These are not the mistakes with which this Note is primarily concerned, but they are relevant insofar as their discovery affects the accuracy of the reporting process.

69. Good credit customers are also injured by false positive reports. The cost of credit is higher because they are required to subsidize bad credit risks who get credit when they should not. 
system would bring errors to the surface, to the benefit of all parties. Only then will grantors be able to choose among credit bureaus on the basis of accuracy and reliability.

\section{Judicial Aspects}

In previous sections, this Note has contended that liability for credit reporting accidents ought to be placed on the credit bureau because it is the cheapest cost avoider. In this section, defamation and products liability will be considered as alternative means of effecting general deterrence.

\section{A. Defamation}

An action in defamation seeks to redress one large group of injuries credit report subjects suffer. ${ }^{70}$ It would not reach other types of harm. Defamation is a tort of strict liability once the expression is shown to be defamatory in nature. ${ }^{71} \mathrm{It}$ is, in theory, a tort based on malice, but the malice is presumed to have existed from the publication of a false and damaging statement and is constructive, not actual. In general, to be defamatory a statement must tend so to harm one's reputation as to "lower him in the estimation of the community or to deter third persons from associating or dealing with him."72 Normally, if slander does not impute to its subject crime, loathsome disease, incompetence at his trade, or unchastity, then specific economic damages must be shown. No such proof, however, is required in libel cases, ${ }^{73}$ and since a credit report is usually written or read from a written statement, it would usually be a libel. ${ }^{44}$

It is defamatory to report falsely that plaintiff refuses to pay his debts, ${ }^{75}$ that he has been indicted or is under indictment, ${ }^{70}$ that he was fired, ${ }^{77}$ dishonest, ${ }^{78}$ a drunk, ${ }^{79}$ that he rwas engaged in immoral activity, ${ }^{80}$ or was having marital trouble, ${ }^{81}$ or went bankrupt. ${ }^{82}$ These

70. See pp. 1088-39 supra.

71. See W. PROSSER, supra note 18 , at 791 .

72. 3 RESTATENENT OF TORTS $\$ 559$ (1938).

73. See W. ProssEr, .supra note 18 , at 773 .

74. Bander v. Metropolitan Life Ins. Co., 313 Mass. 337, 47 N.E.2d 595 (1943); Ohio

Pub. Serv. Co. v. Myers, 54 Ohio App. 40, 6 N.E.2d 29 (1934).

75. Sheppard v. Dun \& Bradstreet, 71 F. Supp. 942 (S.D.N.Y. 1947).

76. Rudawsky v. Northwestern Jobbers Credit Bureau, 183 Mfinn. 21, 235 N.W. 523 (1981).

77. Gartman y. Hedgpeth, 138 Tex. 73, 157 S.W.2d 139 (1941).

78. Bates v. Campbell, 213 Cal. 438, 2 P.2d 383 (1931).

79. MicKee v. Robert, 197 App. Div. 842 , 189 N.YS. 502 (1921).

80. More v. Bennett, 48 N.Y. 472 (1872).

81. Lyman v. New England Newspaper Pub. Co. 286 Miss. 258, 190 N.E. 542 (1984).

82. Petition of Retailers Commercial Agency, Inc. 342 Mass. 515, 174 N.E.2d 376 (1961). 
are the kind of statements in credit reports that lead to rejection of an application to enter financial transactions.

However, as an approach to recovery for damage from an erroneous credit report, defamation has been unavailing. Defending against charges of defamation, credit reporters can raise "conditional privilege" as an affirmative defense. Credit bureaus have the conditional privilege to defame the persons they report on, and bureaus are liable for defamation only if the plaintiff can prove the defamatory statement was motivated by actual malice..$^{83}$

Conditional privilege is a defense of judicial origin which arose to protect from otherwise strict liability defendants whose statements, made from a sense of legal or moral duty, turn out to be defamatory. ${ }^{84}$ Where courts find that prevailing community moral standards compel an honest man to speak, the conditional privilege protects the speaker from liability if the comment is defamatory. Among those thought to have a moral obligation to speak was the person asked about the solvency of another by a potential creditor.

Although England ${ }^{85}$ refused to extend the privilege to credit reporting bureaus, early American cases were divided on the point. ${ }^{80}$ But now, every state which has considered the question except Idaho and Georgia has extended the conditional privilege to credit reporting bureaus $^{87}$ and requires a plaintiff to prove actual malice on the part

83. The privilege may be lost for reasons other than malice which are not relevant to this Note. They include publication to one whose interest in the information is not legally protected, excessive publication, publication of the matter for some improper purpose, or publication of defamatory matter not reasonably believed to be necessary for the purpose for which the occasion is privileged. See, generally, Hallen Excessive Publication in Defamation, 16 MiNN. L. REv. 160 (1932); Hallen, Character of Delief Necessary for the Conditional Privilege in Defamation, 25 ILL. L. REv. 865 (1931).

84. The doctrine is applied, for example, when a person informs law enforcement all. thorities that another has engaged in illegal activity. Foltz v. Moore McCormack Lincs, 189 F.2d 537 (2d. Cir. 1951), cert. denied, 342 U.S. 871; when lawyers speak to protect the interests of their clients; Krause v. Rabe, 80 N.J.L. 378 (1910).

85. Macintosh v. Dun, [1908] A.C. 390 (P.C.).

86.

No Privilege

Johnson v. Bradstreet Co., 77 Ga. 172 (1886)

Pacific Packing Co. v. Bradstreet Co., 25 Idaho 696 (1914)

Privilege

Trussel v. Scarlet, 18 F. 214 (CC Md. 1882)

Erber v. Dun, 12 F. 526, 4 McCrary 160 (1882)

King v. Patterson, 49 N.J.L. 417, 9 A. 705 (1887)

Ormsby v. Douglass, 37 N.Y. 477 (1868)

Crist v. Bradstreet, 9 Ohio St. Rep. 751 (1886)

87. In addition to those jurisdictions listed in note 86 supra, the following jurisdictions have extended the conditional privilege to credit bureaus:

Stationers Corp. v. Dun \& Bradstreet, 62 Cal. 412, 398 P. 2d 785, 42 Cal. Rptr. 449 (1965); Melcher v. Beeler, 48 Colo. 233, 110 P. 181 (1919); Watwood v. Stores Mercantile Agency, Inc., 194 F.2d 160 (D.C. Cir. 1952); Hooper-Holmes Bureau v. Bunn, 161 F.2d 102 (bth Cir. 
of the bureau in order to recover.88 This has generally prevented recovery against credit bureaus for false and defamatory reports, since express intent to harm is rarely involved.

1947) (Fla. law applied); Putnal v. Inman, 76 Fla. 553, 80 So. 316 (1918); Ideal Motor Co. v. Warfield, 211 Ky. 576, 277 S.TW. 862 (1925); Toothaker v. Conant, 91 Afe. 498, 40 A. 331 (1898); Hanschke v. Merchant's Credit Bureau, 256 Mich. 272, 239 N.W. 318 (I931); Lowry v. Vedder, 40 Minn. 475, 42 N.W. 542 (1889); Retail Credit Co. v. Garraway, 240 Afiss. 230, 126 So. $2 d$ 271 (196I); Mitchell v. Bradstreet Co., 116 Mo. 226, 22 S.W. 358 (1893); Bartels v. Retail Credit Co., 175 N.W.2d 292 (Neb. Sup. Ct. 1970); H.E. Crawford Co. v. Dun \& Bradstreet, 241 F.2d 387 (4th Cir. 1957) (N.C. Iav applied); Pomeroy v. Dun \& Bradstreet, 146 F. Supp. 59 (D. Ore. 1956); Hartman \& Co. v. Hyman, 287 Pa. 78, 134 A. 486 (1920); Cullum v. Dun \& Bradstreet, 228 S.C. 384, 90 S.E.2d 370 (1955); Riley v. Dun \& Bradstreet, 172 F.2d 303 (6th Cir. 1949) (Tenn. law applied); The Bradstreet Co. v. Gill, 72 Tex. 115, 9 S.W. 753 (1888); Woodhouse v. Powles, 43 Wash. 617, 86 P. 1063 (1900). Contra, Denney v. Northwestern Credit Assn., 55 Wash. 769 (1909) (dictum); Barker v. Retail Credit Co., 8 Wis. 2d 664, 100 N.W .2d 391 (1960).

In states where the only law on the subject is dictum, there is often analogous case law in other privilege cases which would make the extension to credit bureaus likely if that were the exact point of the case. Of course, in jurisdictions willing to reconsider the question, the absence of any holding would make reversal easier. There may also be room for distinguishing "mutual protective credit associations" from credit reporting bureaus in some jurisdictions.

88. The harshness of granting the conditional privilege to credit bureaus has occasionally been noted. See 2 DE PAUL L. REv. 69 (1952); 31 TEsT. LQ. 50 (195T); $36 \mathrm{~N}$. DAR. L. REV. 201 (1960).

Some jurisdictions have recognized the hardship created by the privilege and have attempted to ameliorate it. It has been held that the conditional privilege may be destrojed by actual or expressed malice, excessive publication, absence of good hith shown by recklessness, or absence of reasonable grounds to believe in the truth of the report, upon which the jury may find bad faith. Melcher v. Beeler, 48 Colo. 233, 110 P. 181 (1919); Ely v. Mason, 97 Conn. 38, 115 A. 479 (1921); Howland v. Blake Co., 156 Míass. 543, 31 N.E. 656 (1892); Pollasky v. Minchener, 81 Mfich. 280, 46 N.W. 5 (1890); Hansehke v. Mrerchant's Credit Bureau, 256 Mich. 272, 239 N.W. 318 (1931); Hemmens v. Nelson, 193 N.Y. 517, 34 N.E. 342 (1893); Hallen, Character of Belief Necessary for the Conditional Privilege in Defamation, 25 ILL. L. REv. 865 (1931). "Mere negligence," however, will not defeat the privilege. In re Retailers Commercial Agency, 342 Mass. 515, 174 N.E.2d 376 (1961). The meaning of "mere negligence" divorced from absence of resconmble grounds to believe is elusive, for the reasonable man test is a negligence standard.

Other courts have held that malice may be proved by showing recklessness, equivilent to a lack of concern with whether the facts are true or not. ABC Needlecraft Co. v. Dun \& Bradstreet, Inc., 245 F.2d 775 (2d Cir. 1957); Afoore v. Stevenson, 27 Conn. 14 (1858); Gott v. Pulsifer 122 Mass. 235 (1877). Inconsistencies remain. One court held that malice may be shown by proving that defendant "had not made reasonable inquiry and investigation, but had written recklessly ...." Chambers v. Leiser, 43 Wash. 285, 289, 86 P. 627, 628 (1906). Is not the absence of reasonable inquiry a negligence standard?

There is growing recognition that malice is a meaningless term in this context and should be abandoned altogether. W. Prosser, supra note 22, at 822. "The meaning of the word in this context is nothing more than that the publication mas made vithout legal justification." I F. HARpER \& F. JAMEs, ThE LAw OF TORTS, 451 (1956). Some courts which decided to protect credit bureaus on policy grounds have done so by holding that if the bureau had exercised reasonable care to assure the accuracy and accurate trans. mission of information received, it could then assert the conditional privilege. Baskett $v$. Crossfield, $190 \mathrm{Ky}$. 751, 288 S.W. 673 (1920); Toothaker v. Conant, 91 Me 438, 40 A. 331 (1898); Carpenter v. Bailey, 53 N.H. 590 (1873); Montgomery v. Dennison, 363 Pa. 255. 69 A.2d 520 (1949). This is the position of the Restatearent of TorTs, supra note 72, at $\S 594$, which would hold the occasion abused and the protection of the privilege lost by the publisher's lack of belief or reasonable grounds for belief in the truth of the defamatory matter. Id. $\S 605$. The negligence test is the first step toward reality. "There is a widespread and legitimate fear of overcentralizing individual information and then increasing the number of people who, by having access to it, have the capacity to inflict damage through negligence, sheer stupidity, or a lack of eensitivity to the value of 
The first comprehensive policy statement justifying extension of the privilege to credit bureaus is a 1914 law review article by Jeremiah Smith. ${ }^{89}$ Written to rebut the English decision, Macintosh $v$. Dun, ${ }^{00}$ it helped crystalize the "American Rule" and it remains to date the most articulate statement in support of that rule.

If such communications are not protected by the law from the danger of vexatious litigation in cases where they turn out to be incorrect in fact, the stability of men engaged in trade and commerce would be exposed to the greatest hazard, for no man would answer an inquiry as to the solvency of another. . . . [G]an it be desirable to impose conditions of immunity so stringent as to discourage the giving of information and thus diminish materially the probability that the desired information will be obtained by persons in need of it?

Protection of the individual must give way, in this view, to the interests of the business community. Smith asserted that credit information is

personal privacy. Unthinking people are as capable of injuring others by unintentionally rendering a record inaccurate, losing it or disseminating its contents to unauthorized users as are people acting out of malice or for personal aggrandizement. It is simply unrealistic to expect subtle standards of care and basic principles of individual privacy to be consistently understood or implemented by people in clerical positions." Miller, stipra note 29, at 1114 .

The doctrinal confusion is far from over. The most recent case on the subject was one of first impression in Nebraska, Bartels v. Retail Credit Co., 175 N.W.2d 202 (1970). After adopting as law the rule that

[a] publication loses its character as privileged and is actionable if it is motivated

by express or actual malice or if there is such a gross disregard of the rights of the person injured as is equivalent to malice in fact

the court contradicted itself. Credit bureaus, it stated, must use "rcasonable care to as. certain the facts," and a "thorough and complete investigation is required" in orcler to meet its obligation. If this isn't a negligence test, what is?

Nevertheless, if negligence were uniformly held to defeat the privilege there would still be an enormous evidentiary problem. Just as proving the negligence of a giant manufacturer was once an insuperable obstacle to recovery for injury due to defective products, the proof of negligence by a large, computerized information supplier would be nearly im. possible. A presumption of negligence or the application of res ipsa loquitur would be necessary to make recovery a meaningful possibility. A statement in a credit record that a person, whose business has always been solvent, has gone into bankruptcy cvery seven years since the Federal Bankruptcy Act was cnacted would be false and damaging, the result of carelessness, but there may be no evidence at all concerning how that cntry got into the file. If negligence may not be inferred from the exror itself, recovery would usually not be possible since the plaintiff could not satisfy the production burden.

89. Smith, supra note 65 . Smith's article remains the only substantial treatincnt of this subject in legal scholarship. It synthesized previous cases on the subject and provided the original legal and economic justification for the present rule. Prosser cites the article several times in support of his exposition and approval of the rule. W. Prosser, supra note 18 , at $805 \mathrm{n} .71,810 \mathrm{n} .25$. As recently as 1961 , the Massachusetts supreme court in a case of first impression, referred with approval to Smith's article in holding that credlit bureaus are conditionally privileged. Petition of Retailers Commercial Agency, Inc., 342 Mass. 515, 520, 174 N.E.2d 376,379 (1961). The language used is nearly identical to Smith's. "Without such protection few would undertake to furnish information and the cost would be high, if not prohibitive."

90. [1908] A.C. 390 (P.C.). 
so important to the community that its flow must not be impeded by allowing innocent persons defamed in the process to gain judicial relief. ${ }^{91}$ Smith also argued against denying the conditional privilege because of the bureau's profit motive. ${ }^{22}$ He reasoned that profit is not relevant because it is the interest of the recipient of the information, not the method of furnishing it, which the conditional privilege is intended to protect. ${ }^{93}$

In short, Smith contended that if the conditional privilege were not extended, credit bureaus would go out of business due to the cost of defamation suits. This contention is based on the assumption that the demand for credit reports is very elastic, and that a small rise in the cost of reports would cause a large reduction in the quantity of reports purchased and in total dollar sales. This assumption of high elasticity of demand for credit reports is susceptible to very simple, if very crude, empirical verification. If Smith were correct, credit bureaus would not exist in jurisdictions where the privilege is denied. Despite the denial of the privilege in Georgia," Atlanta has more than 20 "credit reporting agencies" including Dun and Bradstreet, a local member of the Associated Credit Bureaus of America, and one of the largest national companies in the field, Retail Credit Corporation..$^{95}$ A recent study ${ }^{93}$ of credit practices among retail furniture and appliance dealers in Boise, Idaho, and Spokane, Washington, suggests the same conclusion. Idaho denies the privilege, Washington extends it. ${ }^{07}$ All dealers studied in both cities offer credit to their customers, both on open account and installment, and the median percentage of credit sales to gross sales approaches $80 \%$ in each city. All banks and finance companies, which carried most of the commercial paper, had extensive information on the borrower, obtained at the time of the loan.

The aggregate of both banks and finance companies showed that approximately $77 \%$ of the borrowers had been checked with a credit bureau. ${ }^{98}$

91. "The real test is whether the harm likely to be done to appliants for credit by mistaken statements of an unfavorable nature, bears so large a proportion to the benefits or advantages likely to be derived by subscribers . . . through the mereantile agency reports, as to render it inexpedient or unjust for the law to afford prima facie immunity to the party making the reports." Smith, supra note 65, at 207.

92. Id. at 297.

93. $r d$.

94. Johnson v. Bradstreet Co., 77 Ga. 172 (1886).

95. Southern Beli TelephoNe Co., Yeilow Pages 312 (Dec. 1969).

96. UNIVERSTTY OF IDAHO, CREDIT PRACTICES OF RETAILERS AND FiNANicers of FuratruRE and Honse Appliances in Two Northwest Crties, (1963) [hercinafter cited as Credrt Practices.

97. See notes $86 \& 87$, supra.

98. Credir Practices, supta note 96, at 49. 
In short, credit granting and investigating practices were found to be nearly identical in two large cities, one with conditional privilege and one without.98

These statistics do not prove, or even assume, that the price or quality of credit reports is identical in places with and without the privilege. But they do demonstrate that even though the privilege is denied, many credit bureaus can be sustained by the market, and creditors continue to get information they require, in most cases from credit reporting bureaus.

In Calabresi's terms, Smith's erroneous assumption is that there could be no general deterrence and that denying the privilege would be a proscription of credit reporting altogether. Because of this error, Smith's article begs the basic question: How should the risk of credit reporting accidents be allocated?

Obviously, in jurisdictions where the privilege is extended, the risk and costs of loss fall on the injured persons; where there is no privilege the credit bureau bears the risk and cost of the damage it does. Without the conditional privilege, normal defamation doctrine would govern. Credit bureaus would be liable, without regard to intent or fault, for the damage defamatory reports do. Strict liability of the enterprise is desirable, ${ }^{100}$ for it would encourage safety precautions, spread losses more widely, and would arguably be more fair. ${ }^{101}$

\section{B. Products Liability}

Accident avoidance, risk spreading and fairness are also the policies behind products liability law. As another form of enterprise liability, this is a promising alternative to defamation because an additional class of injuries could be covered. Not all damaging inaccuracies are defamatory. Any report containing a material error, omission or implication which could reasonably be found to have created a false im. pression of the subject's conduct or character, and to have injured the subject, would arguably be "defective" and present a case in products liability.

Most courts find products liability ${ }^{102}$ by recognizing a cause of action

99. Credit is growing rapidly in England, also, where the conditional privilege has never been extended to credit bureaus. In 1964, almost \$3 billion in installment sales were made, on the basis of credit information supplied primarily by banks. Literaturc discussing the growth of credit in England does not indicate whether or not there arc American-type credit reporting bureaus there, but in any case, creditors get the information. Borrie \& Diamond, The Consumer, SocietY and the Law, 157 (2d ed. 1964).

100. See pp. 1042-46 supra.

101. See pp. 1046-47 supra.

102. For a good analysis of the origins and implications of products liabllity as 
for strict liability in tort ${ }^{103}$ or for breach of implied warranty. ${ }^{104}$ Neither action requires a showing of contractual privity or manufacturer's negligence. ${ }^{105}$ In order to recover for a defective credit report under products liability theory, proof of three common elements would be required: a defective product, which causes personal or property injury, to a user or consumer. Two additional elements must also be considered: whether one may recover for purely economic loss in strict tort liability, and whether an implied warranty may be disclaimed by the manufacturer.

The coverage of products liability has spread rapidly. ${ }^{100}$ Beginning

sui generis, part contract, part tort, see Leff, Contract as Thing 19 Ars. U.L. REv. 131 (1970).

103. W. Prosser, supra note 18 , at $672-78$.

104. Id. at 678-81.

105. Iack of privity has been no bar to a negligence action since AracPherson $v$. Buick Motor Co., 217 N.Y. 382, 111 N.E. 1051 (1916). Among the first of many cases to eliminate the requirement of privity in strict liability suits was Greenman v. Yubs Power Products, Inc., 59 Cal. 2d 67, 377 P.2d 897, 27 Cal. Rptr. 697 (1963); See Prosser, The Assault on the Citadel (Strict Liability to the Consumer), 69 YALE L.J. 1099 (1960). Though privity of contract is not required for recovery under implicd warranty, the scope of protection varies widely. Most states have adopted one of the three alternative forms of $\S 2-318$ of the Uniform Commercial Code:

Section 2-318. Third Party Beneficiaries of Warranties Express or Implied.

Alternative A

A seller's warranty whether express or implied extends to any natural person who is in the family or household of his buyer or who is a guest in his home if it is reasonable to expect that such person may use, consume or be affected by the goods and who is injured in person by breach of the warranty. $A$ seller may not exclude or limit the operation of this section.

Alternative B

A seller's warranty whether express or implied extends to any natural person who may reasonably be expected to use, consume or be affected by the goods and who is injured in person by breach of the warranty. A seller may not exclude or limit the operation of this section.

Alternative $\mathbf{C}$

A seller's warranty whether express or implied extends to any person who may reasonably be expected to use, consume or be affected by the goods and who is injured by breach of the warranty. A seller may not exclude or limit the operation of this section with respect to injury to the person of an individual to whom the warranty extends.

Other states have adopted amended versions of one of the alternatives, while the rest have rejected all three and left the pre-existing case law in effect.

In the strict liability in tort area, RESTATEMrENT (SECOND) OF TORTS $\S 402 A$ (1965) is much more expansive:

(1) One who sells any product in a defective condition unreasonably dangerous to the user or consumer or to his property is subject to liability for phjsieal harm thereby caused to the ultimate user or consumer, or to his property, if

(a) the seller is engaged in the business of selling such a product, and

(b) it is expected to and does reach the user or consumer without substantial change in the condition in which it is sold.

(2) The rule stated in Subsection (I) applies although

(a) the seller has exercised all possible care in the preparation and sale of his product, and

(b) the user or consumer has not bought the product from or entered into any contractual relations with the seller.

106. See Prosser, The Fall of the Citadel (Strict Liability to the Consumer) 50 MIss. L. REV., 791, 798-97 (1966). 
with food, it has been extended to products for intimate bodily use. The expansion has continued to the point that the seller of "any (defective) product" may be held strictly liable. ${ }^{107}$ Despite these sweeping statements, the outlines of products liability are imprecise because a comprehensive judicial definition of "product" is lacking. The implicit limit has been where product merges into service. Sellers of services are generally liable only for negligence. ${ }^{108}$ Obviously, definitional problems arise with regard to credit reports. Are they a finished product or an investigatory service? There have been several approaches to the distinction between product and service.

One early case held that the word "product" imports an article which is made of something and which when made has characteristics which are apparent to the senses. ${ }^{109}$ In another case, Gagne v. Bertran, ${ }^{110}$ plaintiff sued a test hole driller for breach of implied warranty. Defendant had been hired to dig test holes in certain land for the depth of land fill and report to plaintiff, who bought the land relying on the findings. The court stated that implied warranties are not confined to transactions involving the sale or furnishing of tangible chattels.111 But analogizing to cases of doctors, lawyers and accountants, the court ruled that defendant was selling services, as evidenced by the fact that he was paid by the hour. ${ }^{112}$

However, although private investigators charge by the hour, credit bureaus do not. Uniformly they charge a price per report. Although some credit bureaus do undertake individual investigations on request, most sell the reports they have on file and accumulate new ones. If

107. The speed of the expansion can be seen in the rapid transformation of section 102A. The sixth draft, 1961, limited liability to "food for human consumption." Tha next draft (No. 7, 1962) included "other products for intimate bodily use." Tentative draft 10, 1964, reached "any product."

108. The liability of certified public accountants is an example of the ncgligence standard for sellers of services. See, e.g., Ultamares v. Touche, 5 N.Y. 170, 174 N.E. 44 (1931); Escott v. BarChirs, Construction Co., 283 F. Supp. 643 (S.D.N.Y. 1968). See generally Farnsworth, Implied Warranties of Quality in Non-Sales Cases, 57 CouUM. L. REV. 65\$ (1957). The few cases discussing the difference between product and service involve statu. tory or contractual construction, not products liability. In Great Western Broadcasting Corp. v. NLRB, 310 F.2d 591 (1962), it was contended that a television station's advertising time is a product. It was held to be a service since the term was distinguished frotn the phrase "tangible articles" which appeared several times in the statute bcing intcrpreted. But the court went on to say that

In its broadest sense the term 'product' denotes anything which is produced, and since economic activity includes the rendition of services, it is appropriatc, wherc the context otherwise permits, to refer to a completed service as a product.

Id. at 595 .

109. Eldex v. State, $162 \mathrm{Ala}$. 41, 50 So. 370 (1909).

110. 43 Cal. $2 \mathrm{~d} 481,486,275$ P.2d 15, 20 (1954).

111. Id. at 486,275 P.2d at 19 .

112. Id. at 486,275 P.2d at 20 . 
they do not have the report a customer wants they simply report "no report on X." Credit reports do not seem to be services by the Gagne criterion.

Other cases dealing with distinctions between goods and services ask the question whether there is a sale of goods which must comply with the Statute of Frauds. Courts facing product/service distinctions may look to the sale of goods tests for guidance.

One test widely applied in sale of goods question is:

"If the contract be such that, when carried out, it would result in the sale of a chattel" it is a sale of goods.

"If the result of the contract is that the party has done work and labor which ends in nothing that can become the subject of a sale" it is a contract for services. ${ }^{113}$

By this chattel standard, the credit report transaction would be the sale of a product rather than a contract for services, because the endresult of the productive process is an item of personal property which the bureau sells many times.

Another, more intuitive, sale of goods test asks not whether there is a sale of a chattel, but "whether work is the essence of the contract or whether it is the materials supplied."114 The case which propounded this test gave the example of a work of art, in which one pays for the artist's time and talent, not for smeared paint or chipped rock. The test is whether the buyer seeks primarily the component elements of the thing bought or the identity of the producer and his unique production process. These are often inseparable, however, and the buyer seeks both. Arguably, the "essence" of the credit report is the materials-the information supplied-but the collection process and the collector are also important. The "essence test" is too imprecise to give much guidance for products liability. ${ }^{115}$

Although the question is close, credit reports seem to fall on the products side regardless of which of the existing approaches is adopted. Reports have characteristics which are apparent to the senses. The price of a report is computed on the basis of finished work, not per unit of the producer's time, and the transaction involves the sale of a chattel.

In order to be protected by products liability the injured person must

113. Lee v. Griffin, 1 B. \& S. 272, 277, 121 Eng. Rep. 716, 718 (1861); 2 A. Connw, CoNTRACTS $\S 476$ (1950).

114. Clay v. Yates, H. \&: N. 73, 75, 156 Eng. Rep. 1123, 1125 (1850).

115. Despite its vagueness, or perhaps because of it, several courts have used this test in rejecting implied warranties. Ladd v. Reed, 320 Mich. 167, 20 N.W.2d 822 (1958); York Heating Co. v. Flannery, 87 Pa. Super. 19 (1926). 
be a consumer or user of the product.110 This limitation is based on the seller's ability to foresee the use to which the product will be put, and the persons most directly endangered if the product is defective. Liability is imposed on the producer so that losses may be spread as widely as possible consistent with our accident deterrence goals. Thus, producers must cover the losses of persons whose direct contact with the product is reasonably foreseeable as being intended by the buyer. The foreseeability requirement is more a matter of policy than of fact. It represents the belief that responsibility must be cut off at some point, and that the arbitrary point chosen should not cut off from recovery the persons most seriously endangered by a defect.

Among those foreseeable as users are those "who are passively enjoying the benefit of the product, as in the cases of passengers in automobiles and airplanes." "117 Others protected as users were a dentist's patient, injured when a defective hypodermic needle broke off in his mouth, 118 and the beauty parlor patron, injured by unsafe hair products. ${ }^{110}$ These, like the subject of the credit report, are persons whose contact with the product is intended by the buyer when the purchase is made. Credit reports are consumed in the active sense by the credit grantor, but the subject is a passive beneficiary of the product, because the report is bought for use in a transaction with him. If the car maker can foresee that persons other than the buyer will ride in the car, and can evaluate the risks accordingly, the credit bureau should, as a matter of policy, be found to "foresee" the unavoidable contact between buyer, report and subject.

The final element of the products liability action is injury. One troublesome question is the kind of injuries for which recovery will be allowed. When food was the only product covered by strict liability, liability was limited to physical injury to the person. Liability was extended to physical injury to property when pet food makers were held strictly liable. ${ }^{120}$ This extension has been made because any defective product can be harmful. And while the consumer's physical

116. This is necessarily an overgeneralzation. See note 105 supra.

117. Restatement (SECOND) OF TORTs, Explanatory Notes, $\$ 402 A$, comment 1 at 854 (1965).

118. Magrine v. Spector, 100 N.J. Super. 223, 241 A.2d 631 (1968).

119. Garthwait v. Burgio, 153 Conn. 284, 216 A.2d 189 (1965).

120. McAfee v. Cargil Inc., 121 F. Supp. 5 (S.D. Cal. 1954). Thus, the physical injury limitation is basically historical. The type of damages allowed has followed the kind of injuries which give a legal cause of action. If economic losses caused by defcctive products are otherwise within the policy of products liability, the physical injury rule is irrelevant and should be disregarded. 
safety is paramount, his property interests are also deserving of protection against the risks created by others.

While recovery for purely economic loss is often permitted under implied warranty, ${ }^{121}$ the second Restatement of Torts extends strict tort liability only for physical harm to the user or his property. ${ }^{120}$ Thus, the manufacturer's liability for economic loss would be excluded in jurisdictions following this section strictly when no physical injury accompanies it. Two leading jurisdictions have clashed over this issue. California followed the Restatement of Torts section 402A in Seely v. White Motor Co. ${ }^{123}$ by limiting strict tort liability to physical injury to the user and his property. It reasoned that economic losses are basically commercial and should be recoverable only on the basis of warranty. However, in Santor v. Karagheusian, ${ }^{124}$ New Jersey refused to apply a physical damage limitation. The court stated that strict liability is based on the producer's responsibility for defects, not on the categorization of damages, and if the manufacturer is to be made liable for the damage his products do to a user he should be liable for all of it.

The New Jersey rule is preferable because it is grounded in the policy objectives of enterprise liability-to make the cost of accidents part of the price of the product, thereby reducing the number of accidents, and spreading all losses as widely as possible. It is not dependent on an artificial distinction between damages of a commercial or noncommercial nature, a distinction which has only a tenuous basis in history and policy. ${ }^{125}$ The risk to the subject and his property

121. Spence v. Three River Builders and Masonry Supply, Inc, 353 Mfich. 720. 90 N.W.2d 873 (1958); Hoskins v. Jackson Grain Co., 63 So. 2d 514 (Fla. 1953); Lang v. General Motors Corp., 136 N.W.2d 805 (N. Dak. 1965); Continental Copper and Steel Indus. จ. E.C. "Red" Cornelius, Inc., 104 So. 2d 40 (Fla. Dist. Ct. App. 1958). The carliest case to throw out privity also gave damages for loss of profits and goodwill. Miazetti $v$. Armour Co., 75 Wash. 622, 135 P. 633 (1913).

Some courts have held that economic damages are recoverable under implied warranty, but only where there is privity. Price v. Gatlin, 241 Ore. 315, 405 P.2d 502 (1965). Kyter v. General Motors Corp., 214 Tenn. 521, 381 S.W.2d 884 (1964).

122. See note 105 supra.

123. 63 Cal. 2d 9, 403 P.2d 145, 45 Cal. Rptr. 17 (1965).

124. 44 N.J. 52, 207 A.2d 305 (1965).

125. In Seely, supra note 123, the court's main concrn, and the troublesome problem with purely economic damages, is determining what is a defect when goods deteriorate. The problem would have been presented in Karagheusian, supra note 124, had the carpet simply worn out rather than having developed a large, visible line down the center. In cases where the question is what is a defect, the problem is a contractual one, i.e. what did the parties bargain for. The expectations of the parties should gorern and a physical injury Iimitation is defensible. Mistaken credit reports, howerer, do not present this problem, for normally there is no problem identifying a defect, and the bureau would never claim that the parties had bargained for a defective report. In cases like these, the difficult problem the California court sought to aroid would not be present, and the physical damage limitation should not be applied. 
created by the erroneous credit report is not physical. But it is direct and economic. It endangers the subject's income-producing capacity, his economic condition, his ability to enter contractual relations, and his personal reputation. It would be illogical and unfair to allow recovery for economic loss caused by an erroneous report when the anxiety over it causes an ulcer, but to deny it when it does not. In jurisdictions following Karagheusian or allowing recovery for purely economic loss in implied warranty, economic damages done by erroneous credit report would be recoverable, notwithstanding the absence of physical injury.

One potential difference between strict tort liability and implied tort warranty is the possibility that a defendant may disclaim the warranty. ${ }^{126}$ When privity of contract was required, this was often an effective defense to an implied warranty action. But courts began to refuse on public policy grounds to bind the user of a product by a disclaimer he had never seen or assented to. ${ }^{127}$ With the elimination of privity and the recognition that warranty is not a matter of contract, a contractual disclaimer should have no effect, and one view of the area is that

so far as strict liability of the manufacturer is concerned, no reliance can be placed upon any disclaimer. ${ }^{128}$

Of course, there are jurisdictions which hold to the contrary, ${ }^{120}$ and it is still unclear whether limitations on damages set by the manufacturers are enforceable when disclaimers are not. ${ }^{130}$

Thus, credit reporting bureaus may be vulnerable to suit in implied warranty or strict liability as well as defamation. However, opening the courts to suits grounded on an erroneous credit report would not afford every injured person a remedy. These tort actions do not reach

126. See UNIFORM COMMERcial CODE \& 2-816, which opens the way to modification of warranties.

127. Henningsen v. Bloomfield Motors, Inc., 32 N.J. 528, 161 A.2d 69 (1960); Jolly Y. C.E. Blackwell \& Co., 122 Wash. 620, 211 P. 748 (1922). See also Kessler, Contracts of Ad. hesion: Some Thoughts About Freedom of Contract 48 Couvm. L. REv. 629 (1948).

128. W. Prosser, supra note 18 , at $832-34$.

129. Rozen v. Chrysler Corp., 142 So. $2 \mathrm{~d} 735$ (Fla. Dist. Ct. App. 1962). It is still generally a good defense to the retail dealer on a direct sale to the plaintiff. See, e.g., Alaska Pac. Salmon Co. v. Reynolds Metals Co., 163 F.2d 643 (2d Cir. 1947). But cases such as Vandermark v. Ford Motor Co., 61 Cal. 2d 256, 37 Cal. Rptr. 896, 891 P.2d 168 (1964) struck this defense down as contrary to public policy where the product is dangerous to human safety.

130. This would be illogical but possible, since courts have been more lenlent toward the manufacturer's attempt to limit recoverable damages under a warranty than toward the attempt to exclude warranty altogether. See, e.g., American Can Co. v. Horkamus Corp. 341 F.2d 730 (5th Cir. 1965). But there will be no assent to either limitation in the case of a distant consumer or user. 
secrecy, or the harms of coercion, or improper dissemination. ${ }^{131}$ Problems of proving falsity, causation, ${ }^{132}$ or damages ${ }^{133}$ would occasionally be considerable.

\section{Legislative Reform}

Because of these limitations, reliance on existing or developing tort remedies alone to solve the problems caused by credit reports would be misplaced. The remedies will be useful only if bureau secrecy is prohibited, for recourse to the courts requires information not easily obtained by concerned individuals. Legal remedies unaccompanied by legislative regulation of credit bureaus might simply increase industry secrecy. Further, tort actions are remedial, and emphasis on prevention is needed. Definitive standards of operation and disclosure would reduce the incidence of injury by providing for record correction before use, not afterwards. These standards would also be aimed at reducing the types of injury tort actions cannot: coercion by unscrupulous businessmen, and improper dissemination of reports.

The fundamental problem is one of determining the proper mix of specific and general deterrence. The first national standards, the first federal attempt at "specific" deterrence, are set forth in the Fair Credit Reporting Act (FCRA) which went into effect on April 25, 1971. 134 The FCRA requires credit bureaus to:

(1) Follow reasonable procedures to assure maximum possible accuracy of information;

(2) Disclose to the consumer, upon request, the "nature, substance" and sources of information in the file, and recipients of the report within the preceding six months;

131. See pp. 1038-1060 supra.

132. Legal cause varies from jurisdiction to jurisdiction. Each would continue to apply its own rule.

133. Determining damages to the financially ruined plaintiff requires an estimate of total loss of income and economic opportunity for a period with a residual loss for a period thereafter. When the loss is marginal, damages would cover the difference in income, cost or terms caused by the report. Thus, if the subject sought a car loan from a bank at $5 \%$ and a false report prevented him from getting it, and he had to borrow at $18 \%$ from a finance company, he could recover the difference. The most difficult problem is estimating pure loss of opportunity. What is the right to credit worth? It would require some estimate of the economic value of the use of those things he vould have bought during the period he was foreclosed. Thus, if plaintiff rould have bought a car, but was prevented from doing so for two years, he would be entitled to the lost value of the use of the car for the period. Proof vould be most difficult when the application was to open an account, not to buy a specific item. Courts have faced issues like this before, however, and would apply their own defamation and products liability damages rules.

134. Fair Credit Reporting Act, $\$ 8601-622,15$ U.S.C.A. $\$ \S$ 1631-1681t (Supp. 1971). 
(3) Provide an opportunity for a subject to challenge the completeness or accuracy of any item in his file, to record the dispute if it is not resolved, and to correct any error;

(4) Limit access to credit reports to those with a court order, the consumer's consent, or "a legitimate business need for the information";

(5) Delete adverse information which is 7-14 years old;

(6) Notify the subject when detrimental public information is included in a report to be used for employment purposes, or to make sure that the information is current. ${ }^{135}$

Government administration of the Act and bureau compliance with it will be expensive. The cost is both tertiary and primary. This section of the Note will indicate possible ways in which the current legislation could be improved, changes which would obviously entail increased costs. The costs of these alterations cannot be accurately quantified here. Thus, the suggested changes-while not seeking to prevent mistakes at any cost-are based, first, on the belief that the FCRA will provide little accident prevention at present cost levels and, second, on the "rough guess" that the increased cost of the changes, to either the government or the bureaus, would be more than recovered in the resulting reduction in primary costs, the number and expense of accidents. Considerations of equity are also relevant to the cost issue which is present throughout this section, for the amount one is willing to spend depends upon how much one cares about protecting the subject of the credit report from harm. This Note has argued that fairness requires letting the consumer see and challenge his credit record, have recourse against bureaus for injury and place reasonable limits on access to the report. If the net effect of the stricter regulations suggested below were to increase the total of accident and avoidance costs, then this Note would urge the Congress or state legislatures to make the value judgment that greater protection is "more fair" and thus worth the extra money.

The Act will be evaluated in terms of four problems: How well does the Act establish the subject's right to (1) be notified of the existence of the report and inspect it; (2) correct or explain detrimental entries; (3) control access to the report; and (4) be protected by the Act while still pursuing common law remedies.

135. This is a summary. For the full text, see $\$ \S 601.622,15$ U.S.C.A. $\$ \S 1681.1681 t$ (Supp. 1971). 


\section{A. Notification and Right to Inspect}

Statutory regulation ought first to establish the subject's right to inspect his credit record. Bureaus could be required to send a report to every subject periodically, to send reports only to those whose files contain detrimental items, or to notify the subject of the location of the report and his right to inspect it. Alternatively, the burden could be placed on the credit grantor to notify the subject when he is denied credit on the basis of the report and to give him the name and address of the bureau that supplied the report which would then be required to let him see it.

The choice involves a trade-off of effective prevention of accidents against administrative and policing expense. Requiring reports to be sent only to those with negative material in the files would involve sending fewer reports, but the cost of determining which files to send might exceed the cost of sending them all, and a large policing effort to set and enforce standards would be required. ${ }^{130}$ Notifying the subject of the location and right to inspect the report involves lower cost to the bureau, and little policing since there is no discretionary factor. It would be much less effective since not everyone would take the time and trouble to inspect his record. Placing the reporting responsibility on the report user would be wholly inadequate. The erroneous report would be received and acted upon before the notification and correction process would begin. Effective specific deterrence prevents accidents. It doesn't merely try to minimize the harm after the accident occurs. In many cases, the harm would consist of extensive delay and loss of opportunity before the mistake was rectified, if it could be. In cases where the object of regulation is to remove prejudicial or inappropriate material before the report is circulated, the harm cannot be undone. The policing problem would be large, since there would normally be several excuses for rejection. Most creditors do not currently notify rejected applicants. They would avoid the responsibility whenever possible. Since the record will come to the surface eventually, it should be exposed when prevention is easiest and most effective. The most effective and expensive method would be to require the bureau to send a copy of the report to each subject. But by sending the

136. The cost of this method would vary with the method of record-keeping in each bureau. Computerized bureaus with appropriate programs would be able to retrieve selectively without high selection cost. The burden on bureaus without suitable program. ming or still using paper files vould be orerwhelming. 
report before it is used the bureaus would prevent many cases of damage and their accompanying lawsuits. ${ }^{187}$

Bureaus could also be required to notify the subject of any detrimental item which is entered in his record after he has seen the report, thereby alerting him to the possible need for correction of the record. ${ }^{138}$ Effective primary cost reduction requires that the correction process be a continuous one because the information collection process is. One way to meet the need for continuing notice is to require bureaus to send the reports to each subject periodically, perhaps every six months, or once a year. Without some kind of continuous notice a prudent subject will have to examine his file regularly —an expensive, time-consuming, and wasteful method. Few will or could reasonably be expected to do so.

Under the FGRA users of credit reports are required to notify the subject of the name and address of the credit bureau when credit, employment, or insurance is denied, or the terms are made less favorable "either wholly or partly" because of the report. ${ }^{130}$ Although the subject may request disclosure of information from the bureau at any time, the Act does not require the bureau even to notify subjects of the location of the report. This omission emasculates the disclosure requirement. For the reasons elaborated above, total reliance on the credit grantor to notify is the least satisfactory of the possible methods.

While under the Act the credit bureau must disclose the nature, substance and sources of the information contained in the files upon de. mand, ${ }^{140}$ it apparently need not let the subject read the report. Further, the sources of information about the subject's "character, general reputation, personal characteristics and mode of living" need not be revealed. ${ }^{141}$ The identity of the source is essential to any attempt to rebut the statements, which may be based on bad motive, lack of opportunity to observe, or similar grounds. Both accuracy and fairness require that this information be disclosed.142 The only information

137. There is potentially a free rider problem-the use by the consumer of the report he has been furnished for future credit reference. This could be prevented by a certiflcile tion of copies system similar to college transcripts.

138. In some cases the problem of defining "detrimental" exists. For instance, the statement that the subject was sued on a debt and won, ostensibly positive, is detrimental because lenders don't want to lend to "troublemakers." If discretion as to which items must be reported is left to the bureau, extensive policing will be required.

139. Fair Credit Reporting Act \& 615, 15 U.S.C.A. \& 1681m(a) (Supp. 1971);

140. Id. $\$ \$ 609$ (a)(1), (2), (3), 15 U.S.C.A. \$\$ 1681g(a)(1), (2) (8) (Supp. 1971)

141. Id. \& 609(a)(2), 15 U.S.C.A. \& 1681 g(a)(2) (Supp. 1971).

142. The contrary argument is that persons might not give information if their names are revealed. The answer to this is that they are protected from legal liability by the conditional privilege to encourage them to speak. It has not been, and in falrness to the subject, should not be, legal policy to protect informants from social liability. 
which the bureau must release on its own initiative is detrimental public record information furnished for employment purposes. The subject must be notified that the information is being reported by the bureau at the time it is reported. ${ }^{148}$ Even this can be circumvented if the bureau has procedures to keep the information "current." 14 Bureaus will rarely choose to notify. There seems to be no reason why only sensitive public information in employment reports need be current or reported to the subject. But the most critical limitation is that the subject need never be notified when a report containing detrimental private information is being sent to a user, and there is no requirement to keep it current either. Thus, under the Act, a person must be notified that an arrest for reckless driving is being reported to a potential employer (if the bureau has no procedure to make sure the report is current), but the person need not be informed of a "no-pay" report by a merchant. These problems drastically reduce the effectiveness of the statute.

\section{B. Right to Correct or Explain}

The second statutory policy ought to be the subject's right to have mistakes corrected, misleading entries explained or clarified, and irrelevant or obsolete data deleted. Mistakes should be corrected promptly, with the responsibility on the bureau to investigate any alleged mistake. Subjects should be allowed to explain any item they believe is incomplete or misleading, and the explanation should become part of the report. Thus, for example, if a merchant reports the subject is a "no-pay," the subject's explanation that he refused to pay because the merchandise was defective must be included.

Some items are so damaging to credit applicants that their use should be allowed only when the bureau has been required to check the entry for completeness between the request for and issuance of the report. These include notation of arrest without conviction, indictment, liens, lawsuits filed and judgments on appeal.

In case of a dispute over the accuracy or completeness of any item, the FCRA requires the bureau to investigate, unless it

has reasonable grounds to believe that the dispute by the consumer is frivolous or irrelevant .... The presence of contradicting information in the consumer's file does not in and of itself consti- 
tute reasonable grounds for believing the dispute is frivolous or irrelevant. ${ }^{145}$

Standards of relevance or frivolity are left to the bureau. Credit bureaus consider the buyer's claim of defective merchandise to be irrelevant to his refusal to pay. ${ }^{146}$ If this claim need not be investigated, recorded, or reported, few objections to the report will be "relevant." The requirement that the bureau record the dispute after investiga* tion is subject to the same "standards." 147

The standard of currency employed in the act is seven to fourteen years. ${ }^{148}$ This is, arguably, much longer than required to give a comprehensive report and makes it very difficult for a person to make up for and forget past mistakes. These limits do not apply in several situations, including reports used for employment in jobs paying over $\$ 20,000$ per year. ${ }^{140}$ Although any time limit is arbitrary, a time limit of two to three years might strike a better balance between the grantor's right to learn of, and the subject's right to leave behind, things of the past.

\section{Controlling Access to the Report}

Third, access to the subject's report must be limited to those with a "legitimate business interest" in it. To avoid the existing abuses of excessive dissemination, the subject should be the judge of legitimacy. Credit reporting bureaus could be allowed to release reports only to persons who state that they have the subject's consent. Despite the fact that consent is often pro forma, this rule, at a minimum, would insure notice to the person that he may be investigated, and allow him to withdraw from the transaction if he finds the investigation overly objectionable. The subject will give his consent to someone who has a legitimate business interest in the report. Arguably, no one else is entitled to it without his consent. Each credit report should contain a list of those to whom it was furnished. By inspecting the report which could be sent to him periodically, the subject would discover whether there were any unconsented-to disclosures. The report buyer could be made liable for procuring the report without consent, and the bureau could be made liable if it released the report without assurance of consent.

145. Id. \& 611(a), 15 U.S.C.A. \& 1681i(a) (Supp. 1971).

146. See note I4 supra.

147. Fair Credit Reporting Act $\$ \S 611(\mathrm{~b})$-(c), 15 U.S.C.A. $\$ \S 1681$ 1(b)-(c) (Supp. 1971).

148. Id. § 605, 15 U.S.C.A. § 1681 (Supp. 1971).

149. Id. \& 605(b)(3), 15 U.S.C.A. \& $168 \mathrm{Ic}(\mathrm{b})(3)$ (Supp. 1971). 
Although the FCRA requires the bureaus to keep records of those who use a report, the statute requires the subject's consent only when there is no "legitimate business interest"150 on the part of the buyer, tested by the bureau's standards. Given the promiscuity with which the bureaus currently apply this standard, ${ }^{161}$ this limitation is useless.

\section{Protection Under the Act and Common Law Remedies}

Finally, statutory sanctions would be ineffective without an enforcement mechanism. A federal administrative agency should set and police compliance procedures. Since litigation is costly and time consuming for all parties, there should be an administrative mechanism for prompt settlement of minor grievances. For example, the question whether the bureau has charged the subject an unreasonable fee to see his file would be neither economically feasible nor worthy of a court's time. An informal administrative hearing would resolve such matters expeditiously. A federal cause of action should be provided for persons claiming non-compliance with the Act or presenting questions of statutory construction. Finally, any disclosures made pursuant to the Act should be usable as the basis for, or as evidence in, state common law actions, so that the use of the latter actions would not be frustrated by continued secrecy by the bureaus. ${ }^{162}$

The FCRA makes credit bureaus liable only for willful or negligent failure to comply with the Act.163 Thus, civil liability is dependent upon either showing intentional violation or meeting a standard of proof that is usually insurmountable.154

The entire liability scheme is weak, and in some ways counter-productive. The credit bureau discharges its obligation to the subject by following "reasonable procedures"105 to make reports accurate, divulging the contents of his file on request and correcting errors or recording disputes. The report user discharges his obligation by maintaining "reasonable procedures"156 to assure notification. Thus, if a reasonably accurate credit bureau sends an erroneous report to a user which has reasonable notification procedures, but which fails to notify, neither is liable under the FCRA. This, notwithstanding the damage done to the subject, the failure to notify, and the subject's uninterrupted ig-

150. Id. \& 604(8)(E), 15 U.S.C.A. $\$ 1681$ b(3)(E) (Supp. 1971).

151. See p. 1040 supra.

152. See TAN 11-13, 21-29 supra.

153. Fair Credit Reporting Act $\S \S 616,617,15$ U.S.C.A. $\$ \S 1681 n, 16810$ (Supp. 1971).

154. See note 87 supra.

155. Fair Credit Reporting Act $\$ 607$ (a), 15 U.S.C.A. $\S 1681$ (a) (Supp. 1971).

156. Id. § 615(c), I5 U.S.C.A. § $1681 \mathrm{~m}$ (c) (Supp. 1971). 
norance of the location, contents and use of the report. As regards the report user, this is a lower standard of care than negligence, for if it has reasonable procedures there is no liability for occasions of negligent failure to follow them. ${ }^{167}$ If the subject is notified by the user, he must go back to the bureau, and must after "a reasonable period of time (for the bureau) to investigate,"158 argue about the report. No matter what the damage, delay, inconvenience and lost opportunity, no one is liable.

The problem does not end here, however, because the law also provides that

no consumer may bring any action or proceeding in the nature of defamation, invasion of privacy or negligence with respect to the reporting of information against any consumer reporting agency (or) any user of information ... based on information disclosed pursuant (to the Act) except as to false information furnished with malice or willful intent to injure such consumer. ${ }^{160}$

This provision will interfere with common law remedies where they are available. The subject may sue the bureau based on common law, but he may not "base the action" on information disclosed under the FGRA unless he is trying to prove malice against a conditionally privileged bureau. This creates an awkward dilemma. If the subject receives no information under the FCRA, he may sue the credit bureau under common law, but secrecy makes this unlikely and impractical. On the other hand, if the subject is notified and receives disclosure under the Act, he may not use the information in a state civil suit, other than for malicious defamation, even when there is no federal cause of action. This part of the Act will harm rather than help the consumer.

Finally, enforcement and procedural rules are left to the Federal Trade Commission, ${ }^{160}$ and a violation of the law or rules is an unfair trade practice under Section 5 of the FTC Act. The FTC has tremendous leeway and little guidance in setting compliance and en. forcement procedures. Close supervision and regulation will be necessary, for credit reporting bureaus will resist restriction strongly.

157. Id. $\$ \$ 606(c), 615$ (c), 15 U.S.C.A. $\$ \$ 1681 d(c), 1681 \mathrm{~m}(\mathrm{c})$ (Supp. 1971).

158. Id. \$ 611(a), 15 U.S.C.A. \& 1681i(a) (Supp. 1971).

159. Id. \$ 610(e), 15 U.S.C.A. \$ 1681h(e) (Supp. 1971).

160. Id. \$621(a), 15 U.S.C.A. 8 1681s(a) (Supp. 1971). 
Protecting the Subjects of Credit Reports

Adequate legislative standards are basically preventive, while tort actions are primarily remedial. But since even tightly drawn standards will not prevent all injury, an action in tort must be available for the injured. Likewise, since no tort action, however liberally construed, will provide relief to every injured party, a barrier to injury must be erected. Both approaches are necessary if legal accountability is to be imposed, at last, on credit reporting bureaus. 